\title{
ENVIRONMENTAL PERFORMANCES OF AGRICULTURE IN THE EUROPEAN UNION COUNTRIES
}

\author{
Ivana Ilić ${ }^{1}$, Bojan Krstić², Sonja Jovanovic ${ }^{3}$
}

\begin{abstract}
Summary
The strong impact of agriculture on the environment has caused the integration of environmental objectives into the Common Agricultural Policy. In parallel with the development of CAP, attempts have been made to make agricultural production more ecologically oriented. The subject of this paper explores the environmental performance at the level of the European Union, with special emphasis on the environmental performance of the agriculture. The environmental performances of agriculture will be analyzed on the basis of the data on Environmental Performances Index (EPI) for the issue area-Agriculture. The aim of this research is to classify the European Union countries into homogenous groups according to the level of achieved environmental performance of agriculture.
\end{abstract}

Key words: Common Agricultural Policy (CAP), environmental performances, European Union

JEL: Q18, Q51

\section{Introduction}

Growing environmental problems at a global and local level have created the need for the formulation of a series of documents governing the issue of environmental protection. Given the limited level of natural resources and the inability of renewal of resources due to the effects of high level of natural pollution in the European Union, the focus has been on raising the awareness of policy makers of the need to accelerate and enhance the use of environmentally sustainable practices.

Special emphasis is placed on the agricultural sector, which needs to solve two conflicting

1 Ivana Ilić M.Sc., University of Niš, Faculty of Economics, Trg kralja Aleksandra Ujedinitelja no. 11, Niš, Serbia, Phone: +381 645734 347, E-mail: ivanica1404@yahoo.com

2 Bojan Krstić Ph.D., Full Professor, University of Niš, Faculty of Economics, Trg kralja Aleksandra Ujedinitelja no. 11, Niš, Serbia, Phone: +381 18528685 E-mail: bojan.krstic@eknfak.ni.ac.rs

3 Sonja Jovanović Ph.D., Associate Professor, University of Niš, Faculty of Economics, Trg kralja Aleksandra Ujedinitelja no. 11, Niš, Serbia, Phone: +381 18528 655, E-mail: sonja.jovanovic@eknfak.ni.ac.rs

EP 2017 (64) 1 (41-55) 
tasks. On the one hand, there is a need for increased food production due to the accelerated growth of the world population and resorting to chemical preparations in order to achieve large scale production of agricultural products. On the other hand, there is agriculture, as a major human activity, associated mainly with the use of natural resources, which has a direct impact on the environment.

Agricultural policy has traditionally been oriented towards ensuring the availability of necessary food for human consumption. Policy objectives are primarily directed at achieving the desired level of production, meeting the needs of the market, while taking into account the measures and mechanisms for this purpose. This long-standing practice, without regard to the consequences, which may be positive or negative for the environment, has resulted in over-exploitation of natural resources, water pollution, and disruption of the balance of biodiversity. In order to prevent further degradation of the environment through agricultural activities, environmental policy becomes an integral part of the Common Agricultural Policy (CAP), the most important and most comprehensive sectoral policy that provides a high level of support and protection of European agriculture.

The strong impact of agriculture on the environment has caused that the integration of environmental objectives into the Common Agricultural Policy becomes a priority. In parallel with the development of CAP, attempts have been made to make agricultural production more ecologically oriented. One of the institutions that invests a significant amount of work in the solution of agro-environmental problems, highlighting the need for better understanding and monitoring of causality of agriculture and environment is OECD.

„The Common Agricultural Policy (CAP) provides a major opportunity for improving environmental management in the agriculture sector, as farming income depends considerably on CAP support. In this regard, the effects of CAP on the environment should be better analyzed, on the one hand, while, on the other hand, one should also take a look at the impact of environmental measures on agriculture. Environmental efforts pursued through the Common Agriculture Policy need to be better targeted geographically, to maximise their effectiveness over time" (European Commission, 2006).

The subject of this research explores the relationship between the overall environmental performance of the national economy and environmental performance of agricultural production in that country. In other words, the paper analyzes the environmental performance at the level of the European Union, with special emphasis on the environmental performance of the agriculture sector. The environmental performance of agriculture will be analyzed on the basis of the component of the EPI, Ecosystem Vitality, and the issue area within this component - Agriculture. The aim of this research is to classify the EU countries into homogenous groups according to the level of achieved environmental performance of agriculture.

\section{Review of literature}

The primary objectives of the Common Agricultural Policy of the European Union have been set up to promote agricultural production in the region, without taking into 
account the ecological disturbance they make. During the 1960s and 1970s, this policy contributed significantly to the increase in agricultural production in Europe, and was considered as a positive version of growth in the postwar period. However, since the 1980s, the negative effects of increased agricultural production (water pollution and depletion of soil) on the environment began to emerge. Since then, systemic reforms in terms of preventing the negative effects of agriculture on the environment have started. The first indication of the introduction of environmental protection measures, as an important element of agriculture, can be found in Mansholt plan at the end of the 1960s and the beginning of 1970s (European Commission, 2000).

At the European level, the environmental aspect of agricultural production over time has gained increasing importance, especially when it comes to the full implementation of the system to support the price of agricultural products, which led to a significant intensification of production methods and the visible negative effects on the environment (Pezaros, Unfried, 2002). The European Commission, therefore, launched several initiatives related to the development of sustainable agriculture. In this regard, instruments such as agro-environmental measures have gained in importance, with efforts to fully integrate environmental policy into CAP. Reform of the CAP in 1992 and Agenda 2000 were major steps towards regulation of measures and instruments of this policy relating to the environmental aspect of agriculture.

The first in a series of CAP reforms, with substantial changes in terms of environmental protection in agricultural production, is Mac Sharry reform of 1992. This reform brought several structural changes in the functioning of agricultural production, and one of them was related to the introduction and support of agro-environmental measures and afforestation of agricultural land. Major innovation resulting from the Mac Sharry reform was the introduction of environmental protection measures (Drost, 2013). These protective measures were applied in the form of subsidies to agricultural producers, cultivating good environmental practice (Institute for agriculture and trade policy, 2007).

Since 1992, CAP has been gradually adjusted to take into account objectives of sustainability, including environmental protection, with a move away from price support to production towards support measures to income of farmers, through direct payments and rural development measures (European Commission, 2013). Furthermore, the reform envisaged increase in costs from year to year through the acceptance of agroenvironmental measures by the European Union member states. Despite the anticipated efforts of the CAP, agricultural support remained high, while environmental protection was minimal, which pointed to the need for additional reforms.

Agenda 2000 was created in 1999 with the aim of highlighting the importance of survival of the environment. It has introduced several innovations related to the environment, and defined a large number of new provisions, one of which was the introduction of a framework for rural development as well as the horizontal rules for direct support schemes to connect with the environment and other non-market criteria 
(Pezaros, Unfried, 2002). These changes represent a significant step forward towards the integration of environmental issues and sustainability issues in the CAP, with a commitment to a multifunctional approach to agricultural production (Phelps, 2007). One of the priority objectives, implicitly presented in Agenda 2000, is the protection of the environment, with special CAP pillar aimed at rural development policy. More specifically, the second pillar emphasizes the importance of sustainable agriculture and environmental protection (Madžar, 2002).

The emergence of CAP in the era of food shortage in Europe aimed at ensuring sufficiency in food for the European population regardless of the environmental consequences of such production. This practice was changed significantly by Agenda 2000, which puts the focus on the manner and conditions under which the food is produced, with an emphasis on a balanced relationship between economic activity and the natural environment. It was imperative to reduce the impact of economic activities on the environment and strengthen the environmental protection by CAP provisions. This was achieved by using agro-environmental measures, which are an obligatory part of the rural development program of member states, whose realization is controlled by the European Commission (European Commission, 2000). Agricultural producers, supported by the European Union through direct payments, had the obligation to respect the principle of sustainable agricultural production, i.e. comply with the goals of environmental protection. In other words, the introduction of a new pillar entailed the transfer of funds, diverting funds to support farmers through direct subsidies to sectors and functions related to the provision of public goods (environmental protection and rural development functions) (Janković, 2009). The real effects of Agenda 2000 and earlier Mac Sharry reform of 1992 laid the foundations for later reform activities.

Assessment of the results achieved in previous reforms made clear the need to increase efforts to achieve the initial goals. In order to achieve this, it was necessary to integrate the new guidelines into CAP, which was the basis for the next reform. In 2003, a new CAP reform cycle was initiated, because of the large subsidies to agricultural practices that were not consistent with the protection of the environment and the regulatory framework for food security, called Fischler reform (Swinnen, 2008). The basis of the reform consisted of the provision of economically viable agriculture, while strengthening its market orientation and increasing food security and quality, preventing the concentration of households that harms the balance of the natural environment, and fairer distribution of direct aid between farmers, to make environmental problems better integrated into the CAP support system and strengthen rural development policy (Garzon, 2006).

As previous reform imposed the obligation to respect environmental regulations in agricultural production, this reform introduced the obligation to harmonize production with food security rules for farmers who get help through direct payments. Key innovation was the introduction of the single payment scheme for farmers of the European Union, independent of production volume. Using the single payment scheme abolished the link between production and subsidies, and one of the reasons for this 
was to improve the ecologically and economically sustainable agriculture (Božić et al., 2011).

Health check of 2008 relates to the improvement of the solutions brought by reforms in the period 1992-2003, not in the sense of radical changes to existing measures, but only regarding their adjustment to the new challenges of the XXI century. The aim of this endeavor was to make single payment schemes more efficient and easier, and to anticipate ways to face the challenges in terms of climate change, growing consumption of biofuels, water management, use of renewable energy, and biodiversity protection (Preparing for the "health check" of the CAP reform, 2007). When it comes to climate change (changes in precipitation, extreme weather conditions, temperature levels, water availability), farmers should get assistance in overcoming these problems, which they previously did not encounter. Rural development policy was more directed towards preserving the environment, protecting biodiversity, and water management through appropriate policy of cross-compliance of agricultural activities financially supported by the European Union and preservation of the environment, human, animal, and plant health protection.

Due to the increasingly pronounced challenges and risks in the sector of agriculture, rural development policy has had to assume greater importance, as well as a higher amount of funds for the second pillar of the CAP. Another improvement of the CAP special measures through Health check related to the support to farmers producing milk, beef, goat, and sheep meat and rice in disadvantaged regions or vulnerable agricultural species, and for certain agricultural activities that require additional agroenvironmental benefits (Timerman, 2009). Apart from this, specific support may be granted to improve animal welfare standards, and can be used for risk management (insurance schemes for natural disasters and mutual funds for animal diseases).

The last reform of the CAP was carried out in 2013, when new CAP for the period 20142020 was adopted, in line with the ruling EU development strategy, Europe 2020. This strategy defined the leading targets for the future, and the main initiatives to be taken in order to achieve the objectives, including sustainable growth implying low carbon level, efficient sustainable use of available resources, protecting the environment while preventing the loss of biodiversity and reduction of pollution, the development of new green technologies and production methods, and others (Europe 2020). Building on the objectives and initiatives of the Europe 2020 strategy, CAP 2014-2020 defines new goals and provides for new measures in terms of environmental conservation and respect for the principles of ecological development. 
Figure 1. Historical development of the CAP

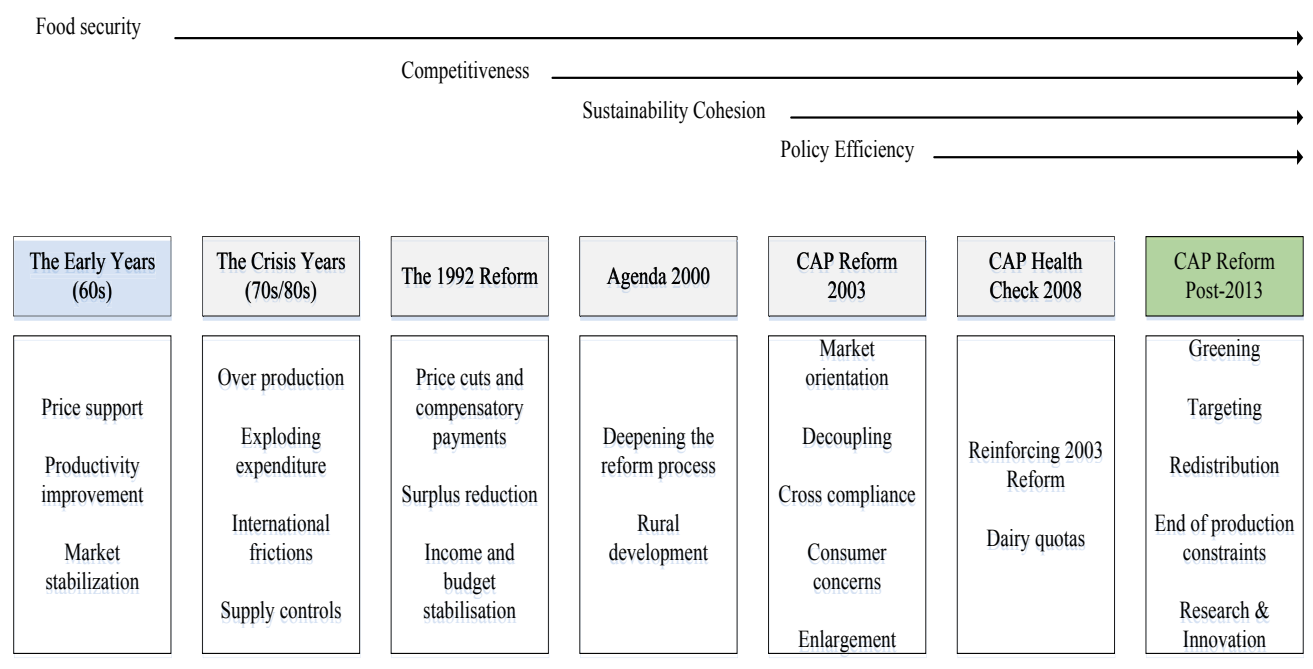

Source: European Commission, The history of the CAP

Three main objectives of long-term CAP 2014-2020 are: stability in food production, sustainable management of natural resources and climate change, and balanced territorial development (Overview of CAP Reform 2014-2020, 2013). For the analysis in this paper, goal of sustainable management of natural resources and climate change is particularly important. The measures provided for achieving this objective include supporting the "green growth" through innovation and application of new technologies, development of new products, changes in production processes. It is particularly important to continue to mitigate the impact of climate and gradually adapt agriculture to the effects of extreme climate change. The novelty introduced by the last reform refers to the "greening" and more uniform distribution of the funds within the first pillar (market support and direct payments), and under the second pillar (rural development), the focus is on climate change, environment, competitiveness, and innovation. Rural development policy has become a key element of the CAP to achieve targeted actions concerning the welfare of the environment at the EU level.

Green direct payments, as a completely new instrument of CAP, are intended for agricultural producers who respect the three mandatory agricultural practices, i.e. diversity of crops, pasture maintenance, and preservation of ecological areas during production. More specifically, they are directed towards production, which is useful for the environment and climate in most of utilized agricultural land (Overview of CAP Reform 2014-2020, 2013). The importance of green direct payments is confirmed by the fact that $30 \%$ of direct payment funds is directed towards them in the future (European Parliament, 2014). Greening as a key feature of recent reforms has become an obligation of all farmers across the European Union, with the degree of realization varying depending on the type of agricultural production. 


\section{Methodology}

For the purpose of considering the situation of the environment, the Environmental Performance Index (EPI) was developed in 2006, whose forerunner was the Environmental Sustainability Index (ESI) of 1999. Environmental Performance Index assesses the environmental performance of a country, observing environmental performance indicators. The main objective of the EPI methodology is to "draw attention to how countries are ahead in achieving the objectives of environmental policy" (Environmental Performance Index, 2010). EPI assesses the social and economic driving forces, pressures on the environment, the state of the environment, and impact on human health and ecosystems (Ilić, Hafner, 2015).

Generally speaking, EPI provides a powerful tool for steering individual countries and the world as a whole toward environmental sustainability (Khayat, 2012). Environmental Performance Index strives to meet the needs of the governments to monitor the achieved environmental performance and offers methods for assessing the efficiency of the environmental policy. EPI ranks countries according to high-priority environmental issues in two areas: Protection of human health and Protection of ecosystems (Environmental Performance Index, 2016). For monitoring the achievement of these two objectives in the context of environmental policy, 9 issue areas are reviewed, with 20 indicators grouped into two key index components, Environmental Health and Ecosystem Vitality. Indicators in the EPI assess countries' proximity to internationally established targets or, in the absence of agreed-upon targets, how individual nations compare relative to the best performing countries (Environmental Performance Index, 2016).

Component Environmental Health covers the Impact on health, and, next to it, the Quality of air and Water and sanitation as the most important issue areas. Under the component Ecosystem Vitality, the following environmental policy issue areas are perceived: Climate and Energy, Biodiversity and Habitat, Fisheries, Forestry, Agriculture and Water resources.

The paper focuses on Agriculture as one of the issue area of the component Ecosystem Vitality within EPI, which will be viewed in more detail, as well as the indicators that it includes in the structure of EPI. The structure of Agriculture, has varied over the years, including the following indicators: Cropland Intensity, Irrigation Stress, Agricultural Subsidies, Pesticide Regulation, and Burned Land Area (Environmental Performance Index, 2008); Agricultural Water Intensity, Agricultural Subsidies, Pesticide Regulation (Environmental Performance Index, 2010); Agricultural Subsidies, Pesticide Regulation (Environmental Performance Index 2012, Environmental Performance Index, 2014); Nitrogen use efficiency, Nitrogen balance (Environmental Performance Index, 2016).

Nitrogen use efficiency as indicator within EPI, allows monitoring of potential environmental damages, as a result of intensive agricultural production accelerated using nitrogen. Specifically, this indicator reflects the proportion of nitrogen inputs (fertilising, nitrogen fixation and nitrogen deposition among other things) and outputs (denitrification and the emission of ammonia among other things) in crop production, 
which are essential for its success. Increasing nitrogen use efficiency is directly linked to the increased productivity of crops, with nitrogen being retained in the soil and affecting the degradation of the environment (Environmental Performance Index, 2016). In agricultural production, farmers induce the production of certain species, releasing reactive nitrogen, which greatly affects the disturbance of the earth's natural nitrogen balance and contributes to changes in the ecosystem, both positive and negative (including increased agricultural productivity in nitrogen-limited areas, ozone-induced injury to crops and forests, over-enrichment of aquatic ecosystems, biodiversity losses, visibility-impairing haze, and global climate change) (Ribaudo et al., 2011).

Nitrogen balance, as an indicator of EPI, measures the level of nitrogen discharged into the environment, as a result of uncontrollable use of fertilizers in agricultural production. The EPI also uses a nitrogen balance variable as a proxy for agricultural drivers of environmental damage. This indicator reflects a nation's efforts to limit excessive use of nitrogen fertilizers, and thus minimize environmental damage (Environmental Performance Index, 2016). Pollution with nitrogen applied in agriculture as contaminant of food achieves a negative impact on air and water quality and leads to ozone depletion and accelerating climate change. In addition to excessive use of nitrogen in agriculture causing a host of environmental problems, it also leads to health problems in humans.

In accordance with the research subject and the corresponding objective, the following initial hypotheses have been defined:

1. Among overall environmental performances of the European Union and the environmental performance of the agricultural there is a positive correlation.

2. Higher level of environmental performance at the level of the national economy means higher level of environmental performance of the agriculture.

\section{Results and discussion}

The 2016 EPI Report covered 180 countries around the world. Of the EU countries, which are of interest in this paper, the best country in the ranking of countries according to EPI index is Finland, occupying the first place. By contrast, Belgium is at the bottom of the list of selected countries, which is positioned in the $41^{\text {st }}$ place. Most European Union countries are highly ranked in the list, with a slightly lower percentage of achieved environmental performance level. Accordingly, among the top ten countries in the world, there are Sweden, Denmark, Slovenia, Spain, Portugal, Estonia, and Malta. Other countries in the group of countries analyzed in this paper are characterized by the high value of EPI, which ranges from 80 to 88, indicating a high level of environmental protection over the years (Figure 2). 
Figure 2. Position of the European Union countries by the EPI in 2016

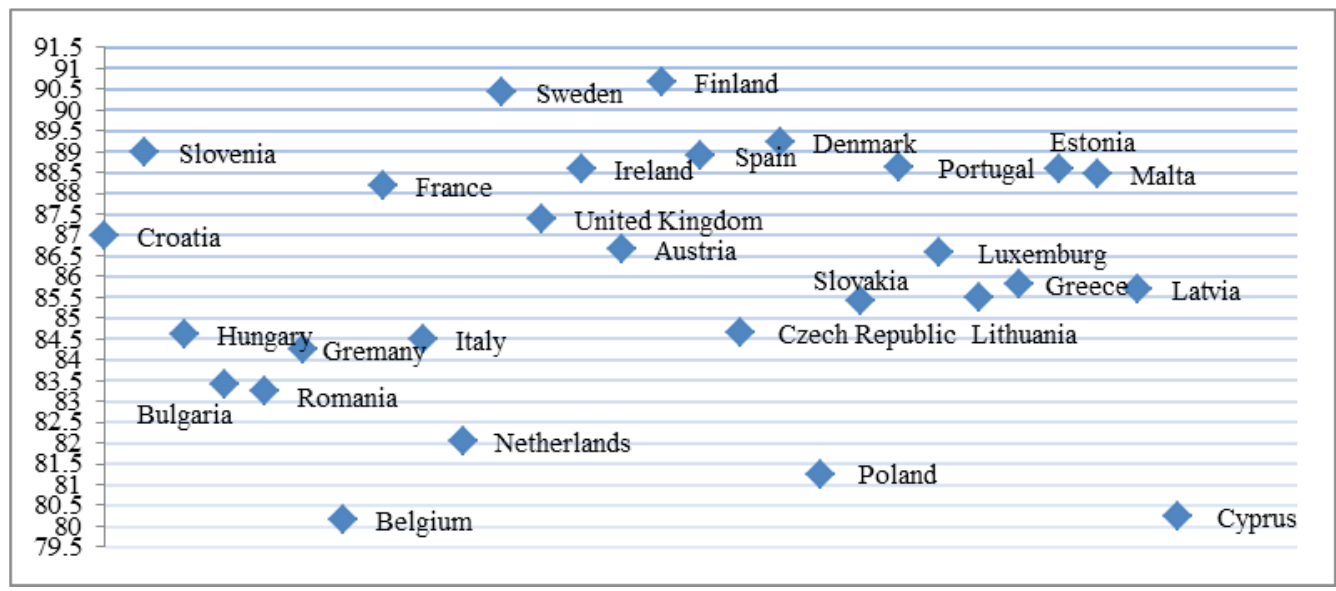

Source: Authors' presentation

Aggregate indicator, Environmental Performance Index (EPI), comprises a number of factors in its structure, which is why further analysis in the paper shall be directed towards the research subject itself, Agriculture, as one of issue of the component Ecosystem Vitality. Following the score of the European Union countries in the framework of Agriculture, it can be noted that Estonia, Greece, Hungary, Portugal, Romania, and Sweden are leading the world in terms of the maximum preservation of the environment when carrying out agricultural activities, whose impact is monitored through nitrogen use efficiency and nitrogen balance. In other countries that are the subject of analysis, there is a large range in values that characterize agriculture, as one of environmental policy issue areas. The weakest environmental protection in agriculture is found in Cyprus, where nitrogen is rather uncontrollably used in production, considered a pollutant to the living environment with harmful effects on water, air, and soil.

In order to investigate the relationship between the level of environmental performance (EPI) and Agriculture, as an environmental policy issue area, correlation analysis was applied. The relationship of the two observed variables is characterized by value of the positive correlation coefficient of 0.368 , while the realized level of significance is Sig. 0.045 (Table 1). Based on this, correlation between the variables is statistically significantly different from zero, where the strength of the correlation, i.e. the degree of correlation between them, is moderate. Spearman correlation coefficient of the environmental performance and agriculture shows the result approximate to the Pearson correlation coefficient, the correlation between variables being of medium intensity. The results of correlation analysis confirm the first hypothesis that between the overall environmental performance of the European Union countries and the environmental performance of the agricultural sector there is a positive correlation. 
Table 1. Correlation of the EPI and issue area - Agriculture

\begin{tabular}{|l|l|r|r|}
\hline \multicolumn{2}{|l|}{} & \multicolumn{1}{|c|}{ EPI } & \multicolumn{1}{|c|}{ Agriculture } \\
\hline \multirow{3}{*}{ EPI } & Pearson Correlation & 1 & 0.368 \\
\cline { 2 - 4 } & Sig. (2-tailed) & 28 & 0.045 \\
\cline { 2 - 4 } & $\mathrm{N}$ & 0.368 & 28 \\
\hline \multirow{3}{*}{ Agriculture } & Pearson Correlation & 0.045 & 1 \\
\cline { 2 - 4 } & Sig. (2-tailed) & 28 & 28 \\
\cline { 2 - 4 } & $\mathrm{N}$ & & \\
\hline
\end{tabular}

Source: Authors' presentation

After establishing the correlation between the selected variables, based on this, the analysis of the classification of EU countries in homogenous groups was carried out. For the classification of countries into homogenous groups according to the value of EPI and value of Agriculture, as one of the issue areas in the structure of the EPI, hierarchical clustering was applied, using the Ward method (method of variance). Based on the square of Euclidean distance between the countries of the European Union according to the EPI value given in the agglomeration scheme, it was found that countries should be classified into three homogeneous groups.

The first cluster according to the EPI values includes: Slovenia, France, Sweden, Ireland, Finland, Spain, Denmark, Portugal, Estonia, Malta, and these are the 10 leading countries in terms of the level of environmental performance. The average value of the EPI within the first cluster is 89 . The second cluster groups those countries whose average value of EPI index is about 85, which are: Croatia, Hungary, Bulgaria, Romania, Germany, Italy, Great Britain, Austria, the Czech Republic, Slovakia, Luxembourg, Lithuania, Greece, and Latvia. More specifically, these are the countries whose EPI value ranges from 83 to 87 . The third cluster includes Belgium, the Netherlands, Poland, and Cyprus, and this is the group of EU countries with the lowest level of ecological preservation (Table 2).

Table 2. Position of the European Union countries by clusters, based on the EPI index

\begin{tabular}{|c|c|c|c|}
\hline Cluster & Frequency & Mean of EPI & Countries \\
\hline $\mathbf{1}$ & 10 & 89.0710 & $\begin{array}{r}\text { Slovenia, France, Sweden, Ireland, Finland, Spain, } \\
\text { Denmark, Portugal, Estonia, Malta }\end{array}$ \\
\hline $\mathbf{2}$ & 14 & 85.3329 & $\begin{array}{c}\text { Croatia, Hungary, Bulgaria, Romania, Germany, Italy, } \\
\text { United Kingdom, Austria, Czech Republic, Slovakia, } \\
\text { Luxemburg, Lithuania, Greece, Latvia }\end{array}$ \\
\hline $\mathbf{3}$ & 4 & 80.9200 & Belgium, Netherlands, Poland, Cyprus \\
\hline Total & 28 & 86.0376 & \\
\hline
\end{tabular}

Source: Authors' presentation

In the same way, the grouping of countries in the European Union according to the value of Agriculture, as a component of EPI was conducted. The analysis gave rise to two clusters, which are mutually noticeably different in terms of the degree of impact of the indicator (nitrogen use efficiency and nitrogen balance) of agricultural production on the environment. Most countries taken for analysis are in the first cluster, which is characterized by a high degree of conservation of nature in carrying out agricultural activities, namely high- 
controlled use of nitrogen as the cause of the increased productivity of manufacturing. In contrast to this group of countries, there are Cyprus, Malta, Luxembourg, Ireland, Great Britain, Netherlands, Belgium, and Germany, which use nitrogen excessively in agricultural production, thereby damaging ecological stability, and ultimately achieving a lower level of environmental performance, which is an important indicator of environmental preservation. Very low average value of performance in the area of agriculture can be seen in the second cluster due to uncontrolled use of nitrogen in agricultural production (Table 3).

Table 3. Position of the European Union countries by clusters according to the values of the EPI issue area - Agriculture

\begin{tabular}{|c|c|c|c|}
\hline Cluster & Frequency & $\begin{array}{c}\text { Mean of } \\
\text { Agriculture }\end{array}$ & Countries \\
\hline $\mathbf{1}$ & 20 & 93.5480 & $\begin{array}{c}\text { Slovenia, France, Sweden, Croatia, Hungary, Bulgaria, } \\
\text { Romania, Italy, Austria, Czech Republic, Slovakia, } \\
\text { Lithuania, Greece, Latvia Finland, Spain, Denmark, } \\
\text { Portugal, Estonia, Poland }\end{array}$ \\
\hline $\mathbf{2}$ & 8 & 57.9175 & $\begin{array}{r}\text { Cyprus, Malta, Luxemburg, Ireland, United Kingdom, } \\
\text { Belgium, Netherlands, Germany }\end{array}$ \\
\hline Total & 28 & 83.3679 & \\
\hline
\end{tabular}

Source: Authors' presentation

Agricultural production of countries listed in the second cluster is of intensive type and represents a huge threat to the environment. The use of pesticides and fertilizers generates a negative impact on people and nature, as shown through numerous studies. Agriculture in these countries is one of the leading sectors of their economy by level of pollution it causes, because it burdens the environment with nitrogen, phosphorus, and heavy metals that disrupt natural biodiversity, destroying certain useful species in the ecosystem. In Germany, the release of nitrogen gas into the atmosphere is alarmingly high, with about $60 \%$ of the emissions originating from agriculture (Federal Environment Agency, 2015). German government is struggling with this situation by introducing stricter regulations and encouraging change in the way of production. On the other hand, Denmark has set a target that, by 2020 , overall agricultural production is converted into $100 \%$ organic and biodynamic production (LifeGate, 2015).

Grouping EU countries according to two criteria, the total value of the EPI and the values of issue area - agriculture, pointed to differences in position by clusters for Ireland and Malta. These two countries, by the global environmental performance, are classified into 10 leading countries of the world, while in respect of agriculture, as an environmental policy issue area, their ranking is very poor, due to the high level of pollution in the performance of agricultural production. The second hypothesis cannot be confirmed due to the deviation that exists in the said countries of the European Union, i.e. one can only partially confirm that higher levels of environmental performance at the level of the national economy mean higher level of environmental performance of the agriculture sector. 
Table 4. Results of the ANOVA procedure for variable EPI and issue area-Agriculture

\begin{tabular}{|c|c|c|c|c|c|c|}
\hline Variable & & $\begin{array}{l}\text { Sum of } \\
\text { Squares }\end{array}$ & Df & Mean Square & $\mathrm{F}$ & Sig. \\
\hline \multirow{3}{*}{ EPI } & $\begin{array}{c}\text { Between } \\
\text { Groups }\end{array}$ & 203.728 & 2 & 101.864 & \multirow{2}{*}{84.356} & \multirow{2}{*}{0.000} \\
\hline & $\begin{array}{c}\text { Within } \\
\text { Groups }\end{array}$ & 30.189 & 25 & 1.208 & & \\
\hline & Total & 233.917 & 27 & & & \\
\hline \multirow{3}{*}{$\begin{array}{l}\text { Agriculture } \\
\text { (nitrogen } \\
\text { use } \\
\text { efficiency, } \\
\text { nitrogen } \\
\text { balance) }\end{array}$} & $\begin{array}{c}\text { Between } \\
\text { Groups }\end{array}$ & 7254.472 & 1 & 7254.472 & \multirow{2}{*}{71.516} & \multirow{2}{*}{0.000} \\
\hline & $\begin{array}{l}\text { Within } \\
\text { Groups }\end{array}$ & 2637.394 & 26 & 101.438 & & \\
\hline & Total & 9891.866 & 27 & & & \\
\hline
\end{tabular}

Source: Authors' presentation

To check the statistical significance of the difference of the average values of the variables (EPI value and environmental policy issue area - agriculture) between clusters, one-way ANOVA analysis is applied. Since in both cases the level of significance is less than 0.05 , it can be concluded that there is homogeneity of variance for the selected variable among the countries of the European Union within the group, and that there are statistically significant differences of average values for the variable between clusters (Table 4).

\section{Conclusion}

Agricultural production at the level of the European Union and at the global level can have a strong positive and negative impact on the environment. Feedback exists in terms of dependence of future agricultural production on the sustainable management of natural resources, primarily considering soil, water, and climate. In this sense, agricultural activities should not be restricted, but appropriate incentives introduced for the development of sustainable production systems and ensuring the protection of the environment. Therefore, recognizing the need for sustainable management of agricultural production and the ecological balance in the European Union, in the course of time a large number of documents which regulate this issue have been defined.

The Common Agricultural Policy has, since its inception to the present day, constantly evolved to reflect the changing needs of agriculture and society at large. Consideration of ecological aspects through CAP dates from 1992 (MacSharry reform), when it was realized that it was necessary to introduce agro-environmental measures, which encouraged farmers to provide environmental services that are much more than the application of good agricultural practices. Coming reforms paid more attention to the survival of the environment and better preservation over time. Thus, Agenda 2000 introduced a new pillar of the CAP, dedicated to rural development policy that emphasizes the importance of sustainable agriculture, environmental protection. Since 2003, there has been an obligation to respect the environmental regulations in the agricultural production and respect the standard of food security and quality. Over time, the CAP aimed at full compliance with environmental 
principles, coping with climate change, tendency to preserve the quality of the environment and biodiversity, and the main novelty introduced were green direct payments to promote greener growth. Greening as a key feature of recent reforms has become an obligation for all farmers across the European Union, with a strong focus on sustainability and environmental performance of agriculture.

The analysis of environmental performance index for the countries of the European Union has pointed to the existence of medium-level quantitative agreement of the positive direction between the achieved environmental performance and environmental policy area-agriculture. In addition, cluster analysis revealed that most of the countries selected for the study take into account the use of nitrogen in agricultural production, thus impacting on the environment in terms of reducing pollution.

\section{Literature}

1. Božić D., Bogdanov N., Ševarlić M. (2011): Ekonomika poljoprivrede, Univerzitet u Beogradu - Poljoprivredni fakultet, DAES - Društvo agrarnih ekonomista Srbije, Beograd

2. Drost, V. S. (2013): The Agricultural Sector in Poland and Romania and its Performance under the EU-Influence, Freie Universität Berlin, Berlin

3. European Commission (2000): The Founding Fathers of the EU, (available at: http:// europa.eu/about-eu/eu-history/founding-fathers/pdf/sicco_mansholt_en.pdf)

4. European Commission (2006): Integrating Environmental Concerns into EU Agricultural Policy, (available at: http://ec.europa.eu/environment/integration/research/ newsalert/pdf/24na2_en.pdf)

5. European Commission (2000): Agenda 2000 - A CAP for the future, (available at: http:// ec.europa.eu/agriculture/publi/review99/08_09_en.pdf)

6. European Commission (2007): Communication from the Commission to the European Parliament and the Council-Preparing for the "health check" of the CAP reform, (available at: http://eur-lex.europa.eu/LexUriServ/LexUriServ.do?uri=COM:2007:072 2:FIN:EN:PDF)

7. European Commission (2010): Europa 2020, (available at: http://ec.europa.eu/eu2020/ pdf/COMPLET\%20EN\%20BARROSO \%20\%20\%20007\%20-\%20Europe\%20 2020\%20-\%20EN\%20version.pdf)

8. European parliament (2014): CAP 2014-2020 Tools to enhance family farming: opportunities and limits (available at: http:/www.europarl.europa.eu/RegData/etudes/ note/join/2014/529051/IPOL-AGRI_NT(2014)529051_EN.pdf)

9. European Commission (2015): The history of the CAP, (available at: http://ec.europa.eu/ agriculture/cap-history/index_en.htm)

10. Environmental Performance Index (2008): (available at: http://www.cm-lousa. pt/_Uploads/agenda21local/docs/6_performance/ENVIRONMENT\%20 PERFORMANCE_INDEX2008.pdf) 
11. Environmental Performance Index (2010): (available at: http://epi.yale.edu/files/2010 epi_report.pdf)

12. Environmental Performance Index (2012): (available at: http://epi.yale.edu/files/2012 epi_report.pdf)

13. Environmental Performance Index - Full Report, (2014): (available at: http://epi.yale. edu/files/2014_epi_report.pdf)

14. Environmental Performance Index - Full Report, (2016): (available at: http://epi.yale. edu/sites/default/files/EPI2016_FINAL\%20REPORT.pdf)

15. Federal Environment Agency (2015): Nitrogen surplus - an environmental problem of entirely new proportions, (available at: https://www.umweltbundesamt.de/en/press/ pressinformation/nitrogen-surplus-an-environmental-problem-of)

16. Garzon, I. (2006): Reforming the common agricultural policy: history of a paradigm change, Basingstoke: Palgrave Macmillan

17. Ilić, I.,Hafner, P. (2015): Environmental aspects of the process of globalization-negative implications and crisis, Facta Universitatis Series: Economics and Organization, vol. 12, no 2, pp. 109 - 120

18. Institute for agriculture and trade policy (2007): The Common Agricultural Policy: A Brief Introduction, (available at: http://www.iatp.org/documents/the-commonagricultural-policy-a-brief-introduction)

19. Janković, D. S. (2009): Evropska unija i ruralni razvoj Srbije, Futura, Novi Sad

20. Khayat, M. (2012): The Role Of Documentation And Measurement Tools In Governing Urban Impact On Environment (A Study on Erbil City Rapid Development), Zaytoonah University International Engineering Conference on Design and Innovation in Infrastructure 2012, Amman - Jordan, (available at: http://www.arbilengineering.com/ publication/final\%20submission\%2029-5-2012.pdf)

21. Life Gate (2015): Denmark, objective 100\% organic, (available at: http://www.lifegate. com/people/lifestyle/denmark-organic-farming)

22. Madžar, L. (2002): Poslovanje sa evropskom unijom - Zajednička agrarna politika, Visoka poslovna škola Novi Sad, (available at: www.vps.ns.ac.rs/Materijal/mat14579. doc)

23. Overview of CAP Reform 2014-2020 (2013), European Commission, Agricultural Policy Perspectives Brief

24. Pezaros, P. D., Unfried, M. A. (2002): The Common Agricultural Policy and the Environmental Challenge, Instruments, Problems and Opportunities from Different Perspectives, European Institute of Public Administration/Institut européen d'administration publique.

25. Phelps, J. R. (2007): Much ado about decoupling: evaluating the environmental impact of recent European Union agricultural reform, Harvard Environmental Law Review, 31, 279. 
26. Ribaudo, M., Hansen, L., Livingston, M., Mosheim, R., Williamson, J., Delgado, J. (2011): Nitrogen in agricultural systems: Implications for conservation policy. USDAERS Economic Research Report, 127.

27. Swinnen, J. F. (2008): The perfect storm: The political economy of the Fischler reforms of the common agricultural policy, Centre for European policy studies- Ceps, Brussels

28. Timerman, P. (2009): The Health Check: further steps to adapt the Common Agricultural Policy to new realities. Egmont European Affairs Paper Royal Institute for International Relations

\title{
EKOLOŠKE PERFORMANSE POLJOPRIVREDE U ZEMLJAMA EVROPSKE UNIJE
}

\author{
Ivana Ilićc, Bojan Krstićc , Sonja Jovanovićc
}

\begin{abstract}
Rezime
Jak uticaj poljoprivrede na životnu sredinu doveo je do uključivanja ekoloških ciljeva u Zajedničku agrarnu politiku (ZAP). Paralelno sa razvojem ZAP, odvija se proces orijentacije poljoprivrede ka većem uvažavanju ekoloških ciljeva. Predmet ovog rada je analiza ekoloških performansi na nivou zemalja Evropske unije, sa posebnim naglaskom na ekološke performance poljoprivrede. Analiza ekoloških performansi poljoprivrede biće izvršena na osnovu podataka o Indeksu ekoloških performansi (EPI) koji se odnose na područje poljoprivrede. Cilj rada jeste klasifikacija zemalja Evopske unije u homogene grupe prema dostignutom niovu ekoloških performansi poljoprivrede.
\end{abstract}

Ključne reči: Zajednička agrarna politika (ZAP), ekološke performanse, Evropska Unija

4 Master Ivana Ilić, Univerzitet u Nišu, Ekonomski fakultet, Trg kralja Aleksandra Ujedinitelja br. 11, Niš, Srbija, Telefon: +381 645734 347, E-mail: ivanica1404@yahoo.com

5 Bojan Krstić, redovni profesor, Univerzitet u Nišu, Ekonomski fakultet, Trg kralja Aleksandra Ujedinitelja 11, Niš, Srbija, Telefon: +381 18528 685, E-mail: bojan.krstic@ eknfak.ni.ac.rs

6 Sonja Jovanović, vanredni profesor, Univerzitet u Nišu, Ekonomski fakultet, Trg kralja Aleksandra Ujedinitelja 11, Niš, Srbija, Telefon: +381 18528 655, E-mail: $\underline{\text { sonja.jovanovic@eknfak.ni.ac.rs }}$

EP 2017 (64) 1 (41-55) 
ECONOMICS OF

AGRICULTURE

\section{CONTENT}

1. Željko Anđelković, Aleksandra Dragin, Sanja Božić, Kristina Košić

EMOTIONAL EXHAUSTION AND JOB SATISFACTION OF TOUR GUIDES IN RURAL AREAS . . . . . . . . . . . . . . 11

2. Sanja Đukić, Danica Glavaš-Trbić, Nikola Banjac

MANAGEMENT PROBLEMS OF RURAL DEVELOPMENT IN FRUŠKA GORA . . . . . . . . . . . . . . . . . . . . 27

3. Ivana Ilić, Bojan Krstić, Sonja Jovanović

ENVIRONMENTAL PERFORMANCES OF AGRICULTURE IN THE EUROPEAN UNION COUNTRIES . . . . . . . . . . . . . 41

4. Nataša Kljajić, Jonel Subić, Zorica Sredojević

PROFITABILITY OF RASPBERRY PRODUCTION

ON HOLDINGS IN THE TERRITORY OF ARILJE. . . . . . . . . . . 57

5. Aleksandar Maksimović, Zoran Grgić, Ferhat Ćejvanović

MULTI-ATTRIBUTE ANALYSIS OF ORCHARD ACCORDING

TO THE INTEGRATED PRODUCTION CONCEPT . . . . . . . . . . 69

6. Ozrislava Milinković, Branislav Jakić, Slobodan Vuksanović,

Dragana Macura, Milica Šelmić

MULTI- CRITERIA DECISION BASED APPROACH

TO SELECTING THE TYPE OF INDUSTRIAL HALLS

USED IN FOOD INDUSTRY $\ldots \ldots \ldots \ldots$. . . . . . . . . . 81

7. Gordana Nikić, Ljubiša Stamatović, Azra Sućeska

EMOTIONAL COMPETENCIES AND PERSONALITY

TRAITS OF MANAGERS IN MODERN AGROBUSINESS. . . . . . . .97

8. Vladimir Obradović, Nemanja Karapavlović

FINANCIAL REPORTING OF COMPREHENSIVE INCOME

IN THE FOOD AND BEVERAGE SECTOR

IN THE REPUBLIC OF SERBIA . . . . . . . . . . . . . . 113 
9. Aleksandar Ostojić, Nebojša Savić, Željko Vaško

CONSUMER ATTITUDES

ON BUYING FISH IN BANJA LUKA . . . . . . . . . . . . . . . 129

10. Radivoj Prodanović, Boris Kuzman, David Jovović, Lazar Ozegović

MARKET AND TRADE OF ORGANIC FRUITS IN SERBIA $\ldots . . .141$

11. Predrag Vukadinović, Aleksandar Damnjanović, Ljiljana Dimitrijević

ANALYSIS OF THE SALES AND INCOMES BETWEEN

DIFFERENT CATEGORIES OF AGRICULTURAL PRODUCTS . . . 157

12. Jugoslav Aničić, Svetlana Vukotić, Goran Maksimović

THE POSSIBILITIES AND LIMITATIONS

OF ENTREPRENEURSHIP DEVELOPMENT

IN AGRICULTURE IN SERBIA . . . . . . . . . . . . . . 171

13. Željko Bjelajac, Marijana Dukić - Mijatović, Joko Dragojlović

FOOD SAFETY AS ONE OF THE MAIN SAFETY $P$

REOCCUPATIONS OF A MODERN MAN . . . . . . . . . . . . . 191

14. Milan Bradić, Ljiljana Kosar, Lukrecija Djeri, Svetlana Vukosav, Vuk Garača

ECO-LABELLING OF ACCOMMODATION FACILITIES

AND ITS PERCEPTION BY RURAL TOURISTS:

CASE STUDY OF VOJVODINA . . . . . . . . . . . . . . 205

15. Vaso Jegdić, Iva Škrbić, Srđan Milošević

MODELS OF ENTREPRENURSHIP DEVELOPMENT

IN RURAL TOURISM DESTINATIONS IN VOJVODINA . . . . . . . 221

16. Duško Kuzović

MUSEUM OF VERNACULAR ARCHITECTURE OF WESTERN SERBIA

- Representative curtilages of the area surrounding middle

course of the river Drina and Podgorina . . . . . . . . . . . 239

17. Branko Mihailović, Zoran Simonović, Nikola Ćurčić

AGRICULTURAL RESOURCES AND DEVELOPMENT

PRIORITIES OF THE MUNICIPALITY OF STARA PAZOVA. . . . . 259

18. Radmilo Nikolić, Aleksandra Fedajev, Vidoje Stefanović, Silvana Ilić

THE AGRICULTURE SECTOR IN WESTERN BALKANS

- SOME CHARACTERISTICS OF DEVELOPMENT. . . . . . . . . . 275

19. Vladimir Njegomir, Rajko Tepavac, Nenad Ivanišević

ALTERNATIVE SOURCES OF FINANCING

ENTREPRENEURIAL UNDERTAKINGS IN AGRICULTURE . . . 295

Economics of Agriculture, Year 64, No. 1 (1-404) 2017, Belgrade 
20. Daniela Nuševa, Kristina Mijić, Dejan Jakšić

THE PERFORMANCES OF COFFEE PROCESSORS

AND COFFEE MARKET IN THE REPUBLIC OF SERBIA . . . . . . 307

21. Svetlana Roljević Nikolić, Predrag Vuković, Biljana Grujić

MEASURES TO SUPPORT THE DEVELOPMENT OF ORGANIC

FARMING IN THE EU AND SERBIA . . . . . . . . . . . . 323

22. ŽeljkoVojinović, Vera Zelenović, DragoCvijanović

PROGRAM OF STATE SUPPORT

TO AGRICULTURAL CREDITING. . . . . . . . . . . . . . . . 339

23. Nikola Vuksanović, Dragan Tešanović, Bojana Kalenjuk,

Milijanko Portić, Marija Knežević

SOCIO-DEMOGRAPHIC CHARACTERISTICS

AS DETERMINANTS OF DIFFERENCES

IN PERCEPTION OF LOCAL GASTRONOMY . . . . . . . . . . . . 359 